\title{
THE SIGNIFICANCE OF BRUSHFIELD'S SPOTS IN THE DIAGNOSIS OF MONGOLISM IN INFANCY*
}

\author{
BY \\ HUGH R. E. WALLIS \\ From the Department of Child Health, Bristol University
}

(Received for Publication January 11, 1951)

The diagnosis of mongolism in infancy is often difficult. Benda (1947) suggests that the incidence is between 2 and 3 per 1,000 live births or possibly higher. The rate over 14 years at Boston Lying-in Hospital was 3.4 per 1,000. Most British observers are incredulous of this figure which may be an indication of a different rate of incidence in this country, or of the fact that mongolism is sometimes not diagnosed until later in life here. The mortality among mongols is very high especially in infancy, and it may be that many of them die without having been recognized as mongols. A survey of the published work indicates that the difficulty of diagnosis at an early age is well recognized. It also gives some clues to a possible diagnostic sign.

\section{Historical}

Langdon Down (1866) is usually credited with the first description of mongolism. Ruhräh (1935) considers on slender evidence that a painting by Andrea Mantegna (1431-1506) includes a portrait of a mongol child. Shuttleworth (1909) and Brousseau (1928) suggest that Seguin in his writings $(1846,1866)$ was referring to mongols when he described ' furfuraceous cretins.' Benda (1947) quotes from Seguin's book, Idiocy and its Treatment by the Physiological Method (1866) the following:

\footnotetext{
' Furfuraceous cretinism with its milk-white rosy and peeling skin; with its shortcomings of all the integuments, which give an unfinished aspect to the truncated fingers and nose; with its cracked lips and tongue, with its red ectropic conjunctiva, coming out to supply the curtailed skin at the margin of the lids.'
}

Benda calls this a precise description of the type, but most readers will agree with him when he speaks later of 'Langdon Down's classic paper on ethnic classification of idiots in which mongolism was described for the first time.'

- Based on a thesis for the degree of M.D. (Cantab.).
During the next 50 years the diagnosis of mongolism received much attention and many of its characteristic features were described.

Mitchell (1876) stated that in a large proportion of cases these idiots were recognized as notably small and weak at birth. He considered that the condition dated from intra-uterine life.

Telford Smith (1896) described the mongol hand, noting particularly the incurved little finger, which he found in ' nearly every case.' For some time this was known as 'Telford Smith's sign.'

Still (1898) emphasized the microcephaly and dwarfism, with late closure of the fontanelles. He noted the large rough tongue and the epicanthic fold, and described a habit of looking out of the corners of the eyes in a sly way.

Thomson (1898) said that the condition can be diagnosed even at the time of birth and added: 'In most cases the axes of the palpebral fissures are abnormally oblique. In a large proportion also there is a marked development of the so-called epicanthic fold of skin at the inner angle of the eye.' In 1907 he pointed out that though the tongue is swollen at birth, the roughness and enlargement of the papillae appear later (at 3 to 9 months), and the fissuring after the second year. He considered that these features were acquired through the habit of sucking the tongue.

Bourneville (1901) noted persistence of the frontal suture in all mongols. He found this also in $8 \%$ of normal white people. Hill (1908) reported a case with congenital cataract. In 1909, Langdon Down's son, R. L. Langdon Down, described abnormalities in the fold-lines on the palm of the hand, namely that there are two instead of three main ones. Shuttleworth (1909) mentioned the advanced age of the mother at the birth of the child.

Pearce, Rankine, and Ormond (1910), dealing with the ocular condition, reported cataract of the lamellar or congenital dot type in 18 out of 28 cases. They stated that very young mongols did not 
exhibit this change, though the youngest of their reported cases was 5 years old.

By this time it was becoming evident that the features of mongolism are variable, and that no single one of them can be considered absolutely diagnostic. West (1901) showed that 'Telford Smith's sign' was present in $33 \%$ of normal children (605 cases), and absent from two of nine mongols he had seen. Fennell (1904) found an epicanthic fold in eight only among 23 mongols. He found the palpebral fissures to be horizontal in three cases and slanting downwards and outwards in one case.

Tredgold (1908) said:

'It is necessary to remember that mongolism
consists in a particular combination of anomalies
rather than in anomalies which are distinctive in
themselves; and there are many ordinary aments
who possess one or more of the features which go
to make up the tout ensemble of the mongol; in
fact I do not know of any single feature of these
persons (with the possible exception of the tongue),
which may not be seen in other aments.'

Even so, in 1917 Weber gave an example of what may happen if one or even two isolated signs should be considered as diagnostic of the condition:

\begin{abstract}
'Mongolism need not, of course, necessarily, be associated with idiocy or imbecility. Thus G. A. Sutherland (Rep. Soc. Stud. Dis. Ch., 1907, vii, 100), showed a girl aged 8 years with shortening and curving of the little fingers, as in the present case, and with the oblique or slanting palpebral fissures, characteristic of the mongoloid type of imbecility but she was perfectly intelligent.'
\end{abstract}

In 1924 Thomas Brushfield, in his thesis for the degree of Doctor of Medicine of Cambridge University, gave an excellent description. He studied 177 cases aged from 2 to 10 years. $\mathrm{He}$ stated that the diagnosis had often been made at birth, and noted that the anterior fontanelle closed late. All his cases had strabismus, and $40 \%$ had epicanthic folds. Cataract was found in three cases, but the eyes were not examined for the ' dot cataract.' Of the iris he said:

'The following varieties of iris were observed. (1) mottled or marbled iris; (2) speckled ... white or very light yellow clearly defined pin-points near the outer margin, generally placed at regular intervals in a ring and appearing to be placed on the iris. I have not been able to find these in the brown iris.'

Crookshank (1924) stated: ' the normal hand has two or three transverse lines; the mongolian imbecile and the orang-utan only one.' Herrman (1925) stated that he saw 40 cases and found a single transverse line in only 10 . In seven of these the abnormality was on one hand only. He also stated that the epicanthic fold is present in all infant mongols, but disappears in about $50 \%$ of cases as they grow older.

Stewart (1926) observed that 'the colour of the iris varies although blue-eyed mongols appear to predominate in this country. When blue, the iris often shows a curious speckled arrangement of the pigment to which Langdon Down first drew attention.'

Brousseau (1928) dealt with the subject exhaustively, and gave references to 467 original works. She omitted the important reference to Brushfield's paper, though that is easily available, as it was printed in the British Journal of Children's Diseases. She said:

'No abnormality has been discovered that is
peculiar to mongolism, and that would therefore
give some indication of the cause of the disorder.
It is a combination of several anomalies rather than
the presence of any one of them that distinguishes
the type.'

In 1933 Penrose stated: 'the iris often shows a curious speckled arrangement of the anterior yellow pigment to which Langdon Down first drew attention.' Penrose listed seven characters: (1) an intelligence quotient between 15 and 29 ; (2) a cephalic index of 0.83 or more; (3) epicanthic fold; (4) fissured tongue; (5) conjunctivitis; (6) transverse palmar line on either hand; and (7) one crease only on the minimal digit of either hand.

He found that almost three-quarters of the mongols have three or more of these characters, but only six out of 350 other unselected mental defectives have three or more. Any defective with four or more of these characters is almost certainly a mongol.

Benda (1939) considered that the previous discrepancies were due to investigators studying the disease at different ages. For instance the skull is normal in size at birth, but becomes microcephalic after six months; and the height is at the lower limit of normal for six years and after that small for the age.

In 1944 Tredgold reiterated his opinion:

- Although the great majority of mongols are easily recognized, there are many defectives who are not mongols but who present some of the features of this condition, and these are known as "semimongols." In fact there is hardly a single feature of mongolism which I have not seen in ordinary defectives, and some of them are found in normal persons.'

Recently attention has been paid to the palmprints and finger-prints of mongols (Cummins, Keith, Midlo, Montgomery, H. H. Wilder, I. W. Wilder, 1929 ; Cummins, 1936 and 1939 ; and Penrose, 1949). Cummins (1939) reported 'departures from the normal which are to be 
regarded as stigmata of mongolism '; but he also stated: 'It must be remembered that as in other constitutional and racial expressions of dermatoglyphic variation the distinctions appear as trends characterizing the group rather than in the occurrence of traits which are diagnostic of the individual case.' Penrose (1950) states that the palm-prints of mongols are highly specific, but there is some overlapping with normal types.

Lowe (1949) described the mongol eye in detail. Of the iris he says (Figs. 1 and 2):

\begin{abstract}
- The speckling . . . is sometimes seen in normal people. It is . . very uncommon in association with other than blue irides. In young mongoloids just beyond the region where the stroma pigment suddenly becomes thinner, the strands tend to bunch at almost regular intervals around a circle concentric with the pupil; where these strands run together pigment collects or the strands remain thicker, thus presenting an appearance of small golden or white splashes.

This speckling was found in 56 patients in the present series (nearly $90 \%$ ). Its appearance has been noted by previous observers, and it is considered a characteristic of mongolism. When the eyes are moist it gives a most attractive appearance to shining blue eyes.'
\end{abstract}

An example of these spots is shown in Figs. 1 and 2.

All children of British race have blue eyes at birth. It seemed, therefore, that it would be of value to investigate a series of infant mongols and determine whether they all had blue irides, and, if so, whether all without exception had spots on the iris.

\section{Investigation}

The newborn babies in the large modern maternity block of a municipal hospital were observed for a

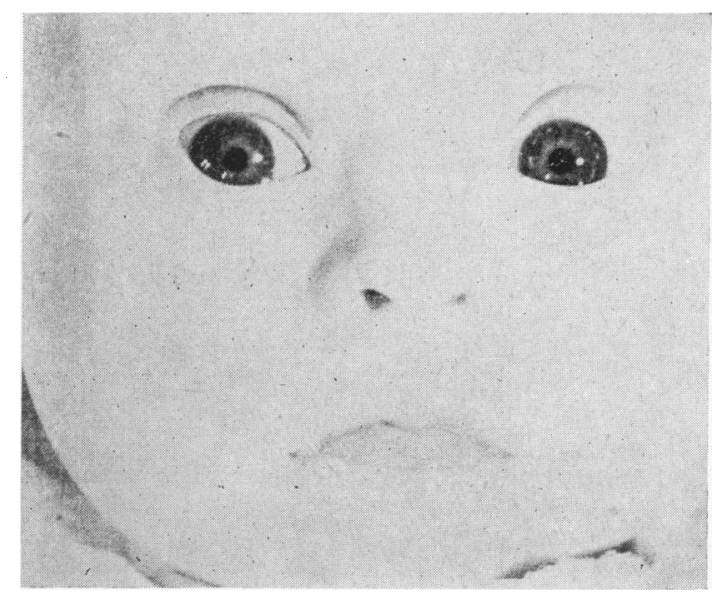

Fig. 1.-The specks are seen best on the left eye arranged in a circle at the junction of the outer and middle thirds of the iris. period of nine months. Approximately 2,250 births occurred, and five mongol children were detected. These five were studied in detail, and seen at intervals

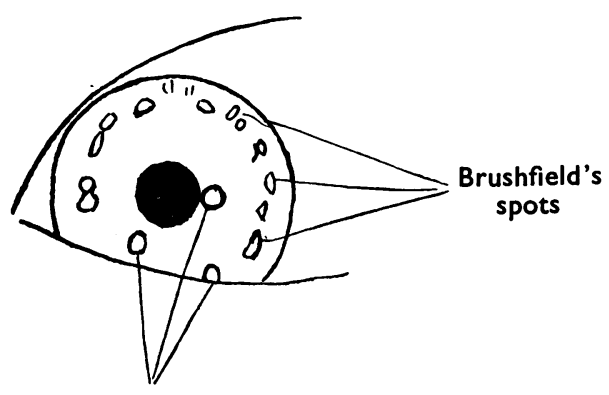

Reflection of studio lights

Fig. 2-Detail of the left eye.

up to two years after birth. Two other mongols (Cases 6 and 7) under the age of 1 year, were also examined.

Attention was directed particularly to the irides, with a view to solving the following problems. (1) Are the spots on the iris confined to mongols?

(2) Are they present in all newborn mongols ?

(3) If so, do they disappear if the iris changes colour from blue to brown or hazel ?

The general findings are summarized in Table 1 and those concerning the irides in Table 2. Three cases $(8,9$, and 10$)$, are included as controls. They were not mongols though they had speckled irides.

The general findings confirm what other workers have found. The mortality rate was very high. The birth weights and head measurements were on the low side of normal. The sutures were more widely open than normal in five cases out of six seen in the first month of life. Other features showed the usual variability. Apart from the irides there was no constant feature: even the tongue was normal in one case.

One child was found to have a dot cataract within a month of birth. Most authors state that this type of cataract does not occur in very young mongols. None of them, however, record evidence of having examined mongols in infancy. It may be that those mongols who have dot cataracts in infancy do not survive to an age at which ophthalmologists begin to study them. This one died at 2 months.

One child had a congenital skin defect, and another suffered from thrombosis of the cerebral veins, due possibly to external version at the seventh month of pregnancy.

The Iris. Investigation of the irides, summarized in Table 2, gave the answers to the three problems.

Spots were seen in infants who appeared to be 
TABLE 1

General Findings Regarding Mongolism in Infancy

\begin{tabular}{|c|c|c|c|c|c|c|c|c|c|c|}
\hline \multirow{2}{*}{$\begin{array}{r}\text { Case No. } \\
\text { Mongols }\end{array}$} & \multicolumn{2}{|c|}{ Age } & \multicolumn{2}{|c|}{$\begin{array}{l}\text { Birth } \\
\text { Weight }\end{array}$} & \multirow{2}{*}{$\begin{array}{l}\text { Head } \\
\text { Circumference } \\
\text { (in.) }\end{array}$} & \multirow[t]{2}{*}{ Sutures } & \multirow{2}{*}{$\begin{array}{l}\text { Palpebral } \\
\text { Fissures }\end{array}$} & \multirow{2}{*}{$\begin{array}{l}\text { Epicanthic } \\
\text { Fold }\end{array}$} & \multirow[t]{2}{*}{ Tongue } & \multirow[t]{2}{*}{ Ears } \\
\hline & M. & F. & & Oz. & & & & & & \\
\hline 1 & 38 & 40 & 5 & 14 & 131 & Open & Oblique & Present & Normal & Abnormal \\
\hline 2 & 37 & 40 & 7 & $0 \frac{1}{2}$ & $12 \frac{1}{2}$ & Open & Oblique & Present & Large & Abnormal \\
\hline 3 & 36 & 36 & 3 & 13 & $11 \frac{1}{2}$ & Open & Oblique & Present & Large & Abnormal \\
\hline 4 & 40 & 42 & 7 & 8 & $12 \frac{3}{4}$ & Open & Normal & Absent & Large & Abnormal \\
\hline 5 & 31 & 35 & 6 & 5 & $12 \frac{1}{2}$ & Normal & Oblique & Absent & Large & Normal \\
\hline 6 & 28 & 29 & 6 & 2 & at 8 months & Normal & Oblique & Absent & Large & Normal \\
\hline 7 & 35 & 36 & 7 & 9 & at 21 days & Open & Oblique & Present & Large & Normal \\
\hline \multicolumn{11}{|l|}{ Controls } \\
\hline 8 & 26 & 30 & 7 & 15 & $13 \frac{3}{4}$ & Normal & Normal & Absent & Normal & Normal \\
\hline 9 & 22 & 23 & 6 & 4 & $13 \frac{1}{2}$ & Normal & Normal & Absent & Normal & Normal \\
\hline 10 & 27 & 30 & 7 & 0 & $\begin{array}{l}17 \\
\text { at } 8 \text { months }\end{array}$ & Open & Normal & Absent & Normal & Normal \\
\hline
\end{tabular}

normal, and were developing normally later in childhood. They have also been observed in normal adults.

In this series of cases all newborn mongols were found to have blue irides with white spots. This is an observation which has not previously been reported. The number of cases is small, and further search is needed.

Case 5 suggests that the answer to the third problem is yes. The baby was seen within a week of birth, and the irides were blue with white specks. At 2 years the irides were brown, and no spots were visible. This is another phenomenon which has not previously been reported. It is thought that this might be the usual course with brown-eyed mongols.

Previous authors have agreed that there is no single constant sign of mongolism. This investigation shows, however, that there is one: speckled blue irides in infancy. Unfortunately normal children may exhibit the same sign. One cannot say, "This baby has speckled irides, therefore it is a mongol.'

The First Description and Suggested Nomenclature

It is interesting to note that both Stewart (1926) and Penrose (1949) attribute the first description of the spots to Langdon Down. But a search of the published works of J. Langdon Down $(1866,1887$, and 1892) and R. L. Langdon Down (1906 and 1909), and of many other workers not included in the list of references below, does not reveal a description of the spots earlier than that given by Brushfield in 1924. Brousseau (1928), despite her 467 references, gives no help in this matter. A standard textbook of ophthalmology (Duke-Elder, 1938) makes no mention of them, but a neurological work (Wilson, 1940) has a description and a picture.

In answer to an inquiry Dr. Stewart wrote in 1947:

' I am afraid I gave Langdon Down the credit of having first noted the speckled iris of the blue eyed mongol when it should have gone to Brushfield. I can remember that it was the late S. A. K. Wilson who first called my attention to it, and when I asked him how Brushfield had found it out he said he thought it was from Langdon Down's description. I believe that is all I can tell you about it except that this condition can, of course, be found in the perfectly normal subject.'

Professor Penrose wrote (1947):

' I am sorry to have been the unwilling cause of your wild goose chase after Langdon Down and speckled irides. If there is no mention of this in 
TABLE 1 (cont.)

\begin{tabular}{|c|c|c|c|c|c|}
\hline Fingers & $\underset{\text { Creases }}{\text { Palm }}$ & Toes & Heart & Other Abnormality & Follow-Up \\
\hline Abnormal & 1R $1 L$ & Normal & Normal & Nil & Seen at one year \\
\hline Abnormal & $1 R 2 L$ & Abnormal & Normal & Nil & $\begin{array}{l}\text { Died } 4 \text { months } \\
\text { (No necropsy) }\end{array}$ \\
\hline Abnormal & $1 \mathrm{R} 1 \mathrm{~L}$ & Normal & Normal & Premature & $\begin{array}{l}\text { Died } 4 \text { months } \\
\text { (No necropsy) }\end{array}$ \\
\hline Abnormal & 2R $1 \mathrm{~L}$ & Abnormal & Murmur & $\begin{array}{c}\text { Congenital skin defect } \\
\text { Atelectasis }\end{array}$ & $\begin{array}{l}\text { Died } 6 \text { days } \\
\text { (Necropsy refused) }\end{array}$ \\
\hline Abnormal & $2 \mathrm{R} 2 \mathrm{~L}$ & Normal & Normal & Nil & Seen at 2 years \\
\hline Abnormal & $1 R \quad 1 L$ & Normal & Murmur & Nil & Went abroad \\
\hline Abnormal & $1 \mathrm{R} 1 \mathrm{~L}$ & Abnormal & $\begin{array}{l}\text { Patent } \\
\text { foramen } \\
\text { ovale }\end{array}$ & Thrombosis of cerebral veins & $\begin{array}{l}\text { Died } 7 \text { weeks } \\
\text { (Necropsy performed) }\end{array}$ \\
\hline Normal & $2 \mathrm{R} 2 \mathrm{~L}$ & Normal & Normal & Nil & Seen at 2 years \\
\hline Abnormal & $2 \mathrm{R} 2 \mathrm{~L}$ & Normal & Normal & Nil & Seen at 19 months \\
\hline Normal & $2 \mathbf{R} 2 \mathrm{~L}$ & Normal & Normal & Syringo-myelocele & Died 9 months \\
\hline
\end{tabular}

the London Hospital Report for 1866, probably my belief that L. Down first noticed these spots is erroneous. I cannot remember now where I got the idea but it is possible that Brushfield may have told me so in conversation.'

Dr. Brushfield was medical superintendent of the Fountain Hospital for Imbeciles, Tooting, from 1914 to 1927. He died on May 17, 1937, at the age of 79. Neither The Lancet nor the British Medical Journal printed an obituary tribute. In 1930 he deposited his papers in the library of the Royal College of Surgeons in London. These papers have been studied. They were very dusty, but did not serve to elucidate the point further. There was no more information about the spots than is given in his thesis, and no reference to any prior description.

The evidence which has been presented proves that he was the first to describe the speckled iris in mongolism. The use of eponyms in medicine has been discouraged recently. But their use adds to bare facts a pride in history. Moreover they are in many cases very convenient if not indispensable. It is suggested that these spots on the iris, so constant in infant mongols, should go by the name of the English physician who first described them, and be called 'Brushfield's spots.'
TABLE 2

FINDINGS REgARDING IRIDES

\begin{tabular}{|c|c|c|c|c|}
\hline & $\begin{array}{l}\text { Case } \\
\text { No. }\end{array}$ & Iris at Birth & Follow-up & Iris Later \\
\hline \multirow{7}{*}{ 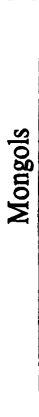 } & 1 & Blue speckled & One year & Blue speckled \\
\hline & 2 & Blue speckled & Died & - \\
\hline & 3 & Blue speckled & Died & - \\
\hline & 4 & Blue speckled & Died & - \\
\hline & 5 & Blue speckled & Two years & $\begin{array}{l}\text { Brown, not } \\
\text { speckled }\end{array}$ \\
\hline & 6 & Not seen & $\begin{array}{l}\text { First seen } \\
\text { at } 8 \text { months }\end{array}$ & Blue speckled \\
\hline & 7 & Not seen & Died & $\begin{array}{l}\text { Blue speckled at } \\
21 \text { days }\end{array}$ \\
\hline \multirow{3}{*}{ 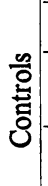 } & 8 & Blue speckled & Two years & Blue speckled \\
\hline & 9 & Blue speckled & 19 months & $\begin{array}{l}\text { Blue-grey } \\
\text { speckled }\end{array}$ \\
\hline & 10 & Not seen & $\begin{array}{l}\text { First seen } \\
\text { at } 8 \text { months }\end{array}$ & Blue speckled \\
\hline
\end{tabular}




\section{Summary}

The published work on mongolism has been studied with particular reference to the possibility of diagnosis in early infancy. Most authors agree that although diagnosis is possible at birth, there is no single constant sign.

A series of infant mongols has been observed and it has been found that all have blue eyes with white spots on the irides. These spots disappear if the colour of the iris changes to brown as the child grows older. The spots are seen in some normal children also, and their diagnostic value is not great except in a negative sense.

The first description of the spots had previously been attributed to Langdon Down, but it has been proved that the credit should go to Dr. Thomas Brushfield. It is now suggested that they should be known by his name.

I wish to thank Dr. R. M. Stewart and Professor L. S. Penrose for permission to quote from their personal communications, and Dr. J. Apley for the photograph.

\section{REFERENCES}

Benda, C. (1939). Arch. Neurol. Psychiat. Chicago, 41,83 . (1947). ' Mongolism and Cretinism.' London.

Bourneville, P. (1901). 'Comptes Rendus de Bicêtre,' p. 137.

Brousseau, K. (1928). ' 'Mongolism.' Baltimore.

Brushfield, T. (1924). Brit. J. Child. Dis., 21, 241.

- (1930). Collected papers in Library of Royal College of Surgeons.

Crookshank, F. G. (1924). ' The Mongol in Our Midst.' London.

Cummins, H. (1936). Anat. Rec., 64, Suppl. 3, p. 11.

- (1939). Ibid., 73, 407.
Cummins, H., Keith, H. H., Midlo, C., Montgomery, R. B., Wilder, H. H., and Wilder, I. W. (1929). Amer.J. phys. Anthrop., 12, 415.

Down, J. Langdon (1866). Clin. Sec. Rep. Lond. Hosp., $3,259$.

__ (1887). "Mental Affections of Childhood and Youth.' London.

- (1892). Cited by Shuttleworth and Beach.

Down, R. L. (1906). J. ment. Sci., 52, 187. (1909). Brit. med. J., 2, 665.

Duke-Elder, W. S. (1938). "Text-book of Ophthalmology.' London.

Fennell, C. H. (1904). J. ment. Sci., 50, 32.

Herrman, C. (1925). Arch. Pediat., 42, 523.

Hill, B. (1908). Quart. J. Med., $2,49$.

Lowe, R. F. (1949). Brit. J. Ophthal., 33, 131.

Mitchell, A. (1876). J. ment. Sci., 22, 174.

Pearce, F. H., Rankine, R., and Ormond, A. W. (1910). Brit. med. J., 2, 186.

Penrose, L. S. (1933). 'Mental Defect.' London.

(1947). Personal communication.

(1949). ' 'The Biology of Mental Defect.' London. (1950). Personal communication.

Ruhräh, J. (1935). Amer. J. Dis. Child., 49, 477.

Seguin, E. (1846). 'Traitement Moral, Hygiène et Education des Idiots.' Paris.

- (1866). 'Idiocy and its Treatment by the Physiological Method.' New York.

Shuttleworth, G. E. (1909). Brit. med. J., $2,661$.

and Beach, F. (1892). D. H. Tuke's ' Dictionary of Psychological Medicine,' vol. 2, p. 664.

Smith, T. T. (1896). Pediatrics, N.Y., 2, 315.

Stewart, R. M. (1926). Proc. roy. Soc. Med., 19 (Sect. Psychiatr.), 11. (1947). Personal communication.

Still, G. F. (1898). King's Coll. Hosp. Rep., 6, 51. Thomson, J. (1898). Scot. med. Surg. J., 2, 203. (1907). Brit. med. J., 1, 1051.

Tredgold, A. F. (1908). 'Mental Deficiency.' London. (1944). Proc. roy. Soc. Med., 38, 216.

Weber, F. P. (1917). Brit. J. Child. Dis., 14, 267.

West, J. P. (1901). Arch. Pediat., 18, 918.

Wilson, S. A. K. (1940). ' Neurology.' London. 